\title{
Managing the menopause through 'abjection work': when boobs can become embarrassingly useful, again
}

\begin{abstract}
This article examines how power and menopause relate at work. Based on qualitative data from 23 women administrative workers, the research finds that menopausal symptoms are sometimes 'awful', 'knackering' and 'isolating'. Yet, as 'real' or 'normal women' they described getting lost in the menopause discourse and many spoke of going through 'the change' instead; this saw them make sense of, and respond to, their symptoms in (sometimes) unconventional ways. In addition, when a menopausal body runs rampant its abject appearance can cause embarrassment, but not just for the woman - for anyone who witnesses it. For some women, they simply go and stand outside. For others, the realisation of the vicarious nature of embarrassment sees them employ their menopausal bodies and do 'abjection work'. This work acts as a powerful form of management; yet, some might argue that it is improper.
\end{abstract}

\section{Keywords}

abjection work, ageing, body work, embarrassment, gender, menopause, older workers, power, resistance, women

\section{Corresponding author}

Clare Butler, Newcastle University Business School, Newcastle University, Barrack Road, Newcastle upon Tyne, NE1 4SE, UK. Email: clare.butler@newcastle.ac.uk

\section{Author biography}

Clare Butler is Senior Lecturer in Work and Employment at Newcastle University Business School, Newcastle University, UK. Her research explores how regulation is enacted, experienced and/or navigated at work; recent studies have considered professionalism and discrimination.

The article is published in the journal 'Work, Employment and Society' and the final copyedited version is available via: https://doi.org/10.1177/0950017019875936 


\section{Introduction}

In the UK, more women over 50 are working than ever before (Phillipson et al., 2016). This shifting workplace demographic has focused attention on a range of issues, including flexible working (Loretto and Vickerstaff, 2015) and health (van der Horst et al., 2017); here, the menopause is in the spotlight, putting older women's bodies centre stage (Brewis et al., 2017; Hardy et al., 2017; Jack et al., 2019). On the one hand, this increased visibility is to be welcomed; opening up space to share knowledge and experience (Loretto et al., 2009). On the other hand, it is somewhat ironic because a great deal of what is spoken and written about the menopause is how to keep it, and its symptoms, hidden (Brewis et al., 2017). The symptoms that women experience during their menopause vary, but fatigue, lapses in memory, low concentration and hot flushes are typical; and are said to cause the most difficulties and embarrassment at work (Hardy et al., 2017; Jack et al., 2019).

In response, employers are encouraged to take an holistic approach to women's menopause in providing information, training line managers and undertaking 'risk assessments' (Jack et al., 2016:88); and by ensuring cold drinking water is available, workwear is not cumbersome and workspace adequately ventilated (Brewis et al., 2017). Alongside, menopausal women are advised to develop 'coping strategies', which might include reframing, seeking counselling or embarking on a well-woman programme (Kafanelis et al., 2009:30). For both workers and organisations then, the aim is to downplay the menopause and instead focus on coping and enablement: how can women enable themselves to undertake their role, despite their menopause; and what can workplaces do to enable women who are experiencing the menopause to perform at work (Hardy et al., 2017). Yet within this framing, women are seen as almost powerless victims of their bodies (Klein and Dumble, 1994); debilitated and in need of help from an effective and emotionally intelligent manager (Hardy et al., 2017; Jack et al., 
2016). Except, are power relations ever that simple? Plus, are bodies ever manageable? [Is yours?!]. There is still much to learn about the menopause at work (Jack et al., 2019). This article adds to our knowledge by furthering our understanding of how power and menopause relate at work.

The article starts by discussing the rise of 'older women' at work. Then, drawing on issues of power, the body and social control (looking to Butler, Foucault, Kristeva and Goffman), it considers the menopause and the way in which the menopausal body is regarded and managed; this includes questioning why the menopausal body needs to be managed, while recognising that not all women experience the menopause and not all women who do are older. The rest of the article is dedicated to the empirical study, which explores how the menopause affects women's working lives. Drawing on the women's stories, the article highlights that the menopause is 'managed' at work; yet, through a range of social and bodily resources, and with varying effects. Embarrassment featured throughout; occasionally subduing, but not always. For some women, the realisation of the multidimensional power of embarrassment saw them employ their menopausal bodies in fascinating ways. To capture this effort, the article contributes to the literature by introducing the concept of 'abjection work'.

\section{The rise of older women}

In the UK, more women over 50 years old are working than ever before; as a result of government policy to extend working lives (Phillipson et al., 2016), financial necessity because of pay inequality (Smeaton and White, 2018), labour market activation policies (Ingold and Etherington, 2013), poor pension provision (Gardiner et al., 2016) or (even) because they enjoy working (Zou, 2015). Yet, despite any enjoyment that may be gained at work, older women are frequently squeezed: sandwiched between caring for children, and maybe grandchildren, while also often supporting elderly parents (Loretto and Vickerstaff, 2015). As such, older 
women's rise at work depends, to some extent, on the resources they able to draw on for support, which includes enjoying good health (Atkinson et al., 2015) and experiencing a 'good' menopause.

\section{The menopause}

The menopause refers to the time at which a woman ceases to menstruate. It is established retrospectively, typically a year following a woman's last period. The average age for the menopause is 51. Women's experience of the menopause differs markedly (Delanoë et al., 2012; Mishra and Kuh, 2006; Perz and Ussher, 2008). There are also what might be called heated debates around what the menopause is; the nature of its effects; and whether it should be treated or not and, if so, how (Ballard et al., 2001; Niland and Lyons, 2011; Woyka, 2017).

Broadly, there are four ways in which the menopause is viewed. The biomedical view considers the menopause as a time of decline and decay (Bell, 1987); an oestrogen deficiency that can be treated with a medical intervention (Padamsee, 2011). The sociocultural view sees the menopause as a natural process, but one which is influenced by culture and discourse (Delanoë et al., 2012). For example, in the West, the menopause is typically associated with deterioration, both physical and mental; in contrast, in Asian cultures, it is generally regarded as a time of liberation and wisdom (Gannon and Ekstrom, 1993). The feminist view is largely that the menopause is both a sociocultural and biological experience, which can result in women's bodies being excessively medicalised and controlled (Green et al., 2002). Others view the menopause as an individual experience (Mishra and Kuh, 2012), shaped by a woman's physiology and personal life circumstance. This individualisation is set within a wider context of self-surveillance (Murtagh and Hepworth, 2003) where it is considered that each woman will experience, and therefore manage, her menopause differently. Much as these views differ, 
the framings and discourses also touch on and talk to each other; importantly, they also affect how women respond to their menopause (Coupland and Williams, 2002).

\section{Managing the menopause: how? and why?}

Some women expect the same menopausal experience as their mother and take no action in response to similarly 'natural' symptoms (Fishman et al., 2015). Whereas, others might visit their doctor with expectations of a medical intervention and lessor symptoms (Bell, 1987). Given concerns of the medicalisation of 'normal' life events and increasing mistrust of medical experts (Smirnova and Owens, 2017), many women take no action to manage their symptoms or adopt self-help strategies (Lyons and Griffin, 2003). The implications of these differing frames and discourses can be significant and include: 1) the worried well; 2) the woman who puts up with 'natural' but debilitating symptoms; or 3) the woman who attributes symptoms to her menopause and fails to seek medical advice when the cause is elsewhere (Nosek et al., 2012).

Yet, we might ask: why does the menopause need to be managed? As an opening gambit, one might look to Wilson (1966:43) a man who suggested that the menopause is a 'living decay'; a condition that definitely needs managing (medically) and for all of our sakes. Here, 'signs of age are read as failure' (Twigg, 2004:61); as a problem to be treated through 'magic bullets' (Estes, 1993:292). The ageing market (or maybe more correctly the anti-ageing market) is often separated along gendered lines (Itzin and Phillipson, 1995), with 'treatments' typically aiming towards allowing men to perform and women to maintain their appearance (Estes, 1993). Clearly, aiming to be active (physically, cognitively and socially) in later life is worthwhile - on which, menopausal treatments are invaluable for many women, supporting a full life - but "there is difference between trying to achieve health and trying to be "not old"" (Calasanti, 2005:12). 
At work, being 'old' can have 'material consequences' (Beck and Williams, 2015; Calasanti, 2005:8): the fetishisation of youth (Farrugia, 2018) and increased aestheticisation of work (van den Berg and Arts, 2019) has assigned a premium to young-looking-fit-looking bodies, which has resulted in many workplaces suggesting not just exercise classes for workers, but exercise regimes (Johansson et al., 2017) - often couched in the discourse of employee wellbeing (Budd and Spencer, 2015). However framed, these management approaches seek 'regularization' towards preferential bodies (Foucault, 2004:247), which through politicisation are constituting of ideals and of valued subjects (Foucault, 1988).

The gendered nature of embodied capital sees bodies of differing gender presentations evaluated differently (Huppatz and Goodwin, 2013). This assessment process establishes those people who are regarded as valuable subjects at work (van den Berg and Arts, 2019); here, older women are hit with a double-whammy of ageism plus sexism (Duncan and Loretto, 2004). It is against this backdrop that women workers have a heightened felt need to hide the signs of ageing (Jyrkinen and McKie, 2012) and an ideal menopausal woman is one who has taken control of her symptoms (Ferguson and Parry, 1998), maintaining an appropriate bodily display (Guillemin, 2000).

\section{Managing the menopause: minimising abjectness?}

Being appropriate and in control of one's bodily display is central to Kristeva's (1982:3) analysis of bodies, bodily functions and the response to 'body fluids'. Despite the naturality of a sweating, sneezing or bleeding body, this leaking often invokes a feeling of disgust. Kristeva argues that it is not the expelled substance that invokes disgust or even the body, per se: rather, it is the individual's unwelcome, leaky ambiguity and lack of self-discipline to allow the outpouring to occur in public. Such an individual is regarded as abject and the process of abjection 'disturbs identity, system, order' (Kristeva, 1982:4). This disturbance of order - of 
public disorder - often leads to the culprit rushing to cover the site of expulsion and hide its outpourings. However, much like the pull of road-kill, the abject and the process of abjection can also represent a compelling spectacle, borne of 'fear and fascination' (Kristeva, 1982:45).

In her discussion of women's situated bodies, Kristeva (1982) focuses on the spectacle of abjectness - the identity clash - that can result. At work, women's abjectness has been associated with their marginalisation when occupying managerial (Mavin and Grandy, 2016) or academic (Fotaki, 2013) roles; or if working while breastfeeding (Gatrell, 2019), being mothers (Haynes, 2008) or menstruating (Shildrick, 1997). Yet, the menopausal woman might lead the way here because as Komesaroff et al., (1997:10) note, 'the menopausal woman is the personification of the abject': degenerating and diminishing, losing vigour and ageing in full sight, which in an increasingly aesthetic, youth-obsessed workplace (Farrugia, 2018; van den Berg and Arts, 2019) is embarrassingly misaligned (Shildrick, 1997).

\section{Managing the menopause or managing embarrassment?}

Embarrassment is a powerful, innate, interactional and multidirectional emotion; arising from the failure to observe a valued social norm (Goffman, 1956, 1959, 1963). In the conventional use of the term, embarrassment is bestowed by others, requiring an embarrassed and embarrassor(s), and with the embarrassor being ascribed greater power (Goffman, 1956). Yet, an audience can also be subjected to embarrassment (Gross and Stone, 1964). Alongside, vicarious embarrassment - being embarrassed on behalf of someone else - can follow our witnessing the social failure of others. Bodies speak/do/act: displaying a 'complex of evidence' (Goffman, 1983:8), sorted into an interactive order, which both reflects and reproduces social norms. Any disruption of the norm disrupts, with the disruptor 'singled out as a malcontent' (Goffman, 1983:6). In face-to-face bodily interaction, 'sex-class makes itself felt' (Goffman, 1977:324) through 'gender displays' (Goffman, 1979:1), which perform the continuous work 
of categorising and differentiating bodies. It is in these scenes that bodily appropriateness is established (and embarrassment avoided); not only in the immediacy of the interaction but among wider social structures (Goffman, 1977). Yet, if this process is continuous, reflecting and reproducing, how established is bodily appropriateness? And, are women's bodies/selves/subjectivities lost or found in this process? Butler suggests both.

Butler $(1989,1990,1993,1997,2004)$ argues that the gendered body is brought into being through an ongoing performativity. To be recognised as a subject, the performance must be coherent and comprehensible within gendered norms (Butler, 1990, 1997, 2004). This coherent production is necessary to be valued as a subject, but success in the doing - 'the performative accomplishment' (Butler, 1990:179) - is accompanied by a loss of complexity the loss of 'the gender discontinuities that run rampant' (Butler, 1990:172-173) - which if/when repeated subordinates and diminishes the subject. Here, the woman's subjectivity is lost.

Yet, while power subordinates subjects through subjection, Butler (1997) argues that subjects are dependent on this process of subjection for their existence. That is, the power that subordinates is embodied within an ongoing process that also brings people into being (Butler, 1990). Here, the woman's subjectivity is found (or has the potential to be). Thus, the power of subjection is also, paradoxically, a power of agency - with agency being 'located within the possibility of a variation on repetition' (Butler, 1990:185).

In the context of the menopause then, women are often assigned to subordinated positions (Coupland and Williams, 2002), but for Butler this creates conditions for agency. Indeed, the 'popularised' doomsayer discourse does not reflect all women's experiences of the menopause (Ferguson and Parry, 1998); these voices are little heard, but many menopausal women describe being more agentic, confident and freer (Dillaway, 2005; Perz and Ussher, 2008). Which begs the question as to why the decaying, diminishing talk persists (Coupland and 
Williams, 2002; Delanoë et al., 2012; Gannon and Ekstrom, 1993; Kaufert, 1982; Martin, 1988); if indeed it does? At work, has the rise of older women moved the conversation on? Jack et al., (2019) highlight that despite the shifting workplace demographic, little is known of the dynamics that surround women's menopause; and how the menopause impacts on women's work participation and working lives (Brewis et al., 2017; Hardy et al., 2017; Jack et al., 2019). The research discussed here addresses this knowledge gap: its aim is to better understand the experience of being an 'older woman' in the contemporary workplace and, specifically, to learn how women navigate the menopause at work.

\section{Method}

The research took place in two phases (2013 and 2018) and involved UK local government administrative staff. In 2013, the research included both men and women and looked to understand their experiences of contemporary work and its impact on their lives. Reflecting work's changing demographic landscape and related academic debates, in 2018 the research focused on older women's experiences of work and their navigation of the menopause.

The article draws on data from 23 women in their 50s (four in 2013 and 19 in 2018); all held back-office, administration roles with no line management responsibility. The data were gathered via 16 semi-structured interviews and two focus group discussions, with one participant, 'Anna', being an interviewee and focus group member. The multimethod approach allowed for both personal and group discussion; capturing participants' experience as an individual, as a woman; and as a collective, as women. On which, I am pre-menopausal and positioned myself as a keen listener, wanting to learn for my upcoming menopause. Open questions were used throughout; for example, asking 'how has your work-life changed in recent years?' and 'any issues with your menopause at work?' Interviews lasted an average of 85minutes and focus groups averaged 50-minutes. The research complied with University ethical 
guidelines and, with permission, sessions were audio-recorded, transcribed and data anonymised.

The data were analysed thematically (Green and Thorogood, 2014) and coded to nodes in QSR International's NVivo 11 software. The nodes were created, amended or merged in a manner that responded to the data and helped to make sense of them (Miles and Huberman, 1994). In practice, this meant that the initial coding was inductive: identifying broad themes, across interviews and focus groups, around the women's working lives: events, colleagues and ageing, including gendered ageing and the menopause. Next, there was a closer examination of the data, which involved re-reading transcripts and re-listening to audio; to capture tone, pace and points of emphasis (Butler, 2015). Here, analysis also returned to the academic debates and social theory; specifically, those around experience and agency. As a result, the final nodes were generated through a process of induction and abduction; speaking to bodily experiences and responses to menopausal symptoms (self and other). This process culminated in three main themes, used to structure the discussion: 1) five senses, and the other one, 2) 'women like us', and 3) abjection work. The women's experiences are sometimes relayed using extended dialogue. This presentation aligns with the sociological ethos of highlighting the experiences of those less heard, giving them voice (Taylor et al., 2009).

\section{Five senses, and the other one}

The women were unclear about when they started their menopause. They spoke of experiencing changes in their bodies - irregular periods and sleeping difficulties - from their late 40s. They remarked that this had a detrimental effect on their work-life, through tiredness, 'tetchiness' (Cleo) and an inability to concentrate (Jack et al., 2019). However, they noted that with so many other things going on at the time - 'kids', 'parents', 'work' - 'tetchiness' was unsurprising 
and maybe, on reflection, not attributable to the menopause at all, given that many of their husbands/male partners were just the same.

When discussing their menopausal symptoms, they often spoke in terms of the five senses: sound, sight, taste, smell and touch. There was a more than heated debate around whether women should tell their work supervisors about their menopause; they all thought that women should speak up, but none of them had. When asked what they would have spoken about, what did they want or need (Hardy et al., 2017) and what prevented them, the response was unanimous: they wanted space to talk 'without sounding like they were moaning' (Dawn) or 'complaining' (Fern), but they did not expect support and so kept quiet. That said, they spoke of the menopause as a strong bonding experience - 'we've got each other' (Cleo) - becoming 'much closer' (Gail) with many of their female colleagues as a result (Jack et al., 2019).

For all the women, the look of experiencing a hot flush at work was a definite concern:

All of a sudden you look like, what's the name of the purple Tellytubby? [children's TV programme]. Tinky Winky, yeah, all of a sudden you're Tinky Winky, without warning. It can be really sodding embarrassing. (Anna)

Reflecting the apparent importance of women's appearance at work (Huppatz and Goodwin, 2013), most participants were concerned about flushes, gaining weight and looking a 'bit frumpy' (Beth); relatedly, they described how the menopause had affected their taste in work clothes:

My taste in clothes these days, shocking. Do you know what I look for? Comfortable, nothing clingy, cool, easily washable and non-iron. Christ, did I just say that? What a state. (Dawn)

Alongside looks, and often with much more emphasis, they spoke of worrying how their bodies smelled (Jack et al., 2019). This was of particular concern for those who worked in open-plan 
offices and/or modern buildings. During a hot flush, 'the disaster that is air-conditioning' (Dawn) meant that they were unable to get fresh air to cool down; and, despite 'showering morning and night' (Cleo), they worried about body odour from stale perspiration. They also remarked, almost with trepidation, that the lack of 'windows that actually open' (Beth) meant that they were unable to get rid of any 'funny odours' (Anna), which might result from mild incontinence or 'leaking through' (Jane) during a heavy blood flow. They spoke of offsetting this lack of air by 'nipping outside' (Rosa); propping the door open when they could 'get away with it' (Anna), as door-propping was against the rules; or 'accidentally [gesturing inverted commas] breaking the hinge, so the door couldn't shut properly. I know, I know, but I did. Don't you dare quote me on that' (Anon).

Alongside using brute force to get access to air, Beth spoke of 'being a bit naughty' in using a friend for much the same reason. When they moved to a new office, she asked a friend in the buildings department for a look at the plans so that she could see where the air vents were located. She then chose a desk that she thought would get good airflow but was not in the line of sight of management. In Foucauldian terms, Beth positioned herself within the gaze of air vents and outside of the gaze of the manager, all facilitated by the panoptic power of a diagram. As Foucault (1979:205) notes 'the Panopticon is a way of defining power relations' and 'must not be understood as a dream building: it is the diagram of a mechanism of power', 'a figure of political technology that may and must be detached from any specific use'. When the office plan was detached from its specific use, its signification was reasserted (Butler, 1990); it became a mechanism of Beth's power and a useful technology of an idealised (cooler) self (Foucault, 1988).

The other sense that was discussed, but one which was said to be lacking was 'common sense', typically from management. 'The managers here are just clueless about women, older 
or otherwise, seriously, even the women [managers]. You only have to look at the uniform they first selected for the front-office girls. They [blouses] had three-quarter sleeves and you couldn't open the buttons around the neck. Just thoughtless' (Jane). Here, the women position themselves as non-managerial; foregrounding their pragmatic, empathetic sensibilities. The first focus group discussion gave rise to another example of a lack of 'common sense', linked to the buying of office furniture and framed around sight and touch:

Whoever decided to buy office chairs with pale grey cushions wasn't a woman on the change or any woman, to be honest. Bleeding and it coming through onto the seat, like hasn't that happened at some time to every woman, but whoever buys furniture doesn't get it. They just don't get it. They've got no common sense. It's not the sort of thing people want to talk about, is it? I understand that, but it's the reality of life, isn't it? We can't all be young and healthy and have light periods, can we? We've all bought cushions. In all shades of black. No shades of sodding grey here. But seriously I mean it's almost as if employers want people, but without the bodies they've got. (Anna, Beth, Cleo and Dawn; Focus Group 1)

Women's messy, leaking bodies challenge social norms (Kristeva, 1982; Shildrick, 1997). Yet, the women challenge and resist these norms (Butler, 1990) by questioning the knowledge (Nosek et al., 2012) and the 'reality' of the knowing (Perz and Ussher, 2008) that informs organisational practice. In so doing, they reject the practices as being against 'common sense' (Foucault, 2004) and make organisations, and management, ridiculous because they want the impossible: disembodied workers - that is, bodies without matter.

\section{'Women like us'}

The range of ways in which the menopause is framed affects how women respond to their symptoms (Coupland and Williams, 2002). For the women in this study (barring two), they did not regard themselves as included within the menopause discourse, as the following conversation shows: 
Cleo: Women like us don't have the menopause, do we, we have the change. It's like the menopause is a middle-class condition and the change is for the rest of us: normal women, you know.

Dawn: Now and again you get stuff coming out from the union or HR [human resources] and I mean most of HR are women, but yoga and mindfulness. Fucking mindfulness. HR are all over the place. They're on about promoting wellbeing and then it's something to do with us being like a health and safety hazard. My friends say the same about their [work]places. And it's the whole menopause business, you know trying to sell you stuff. Wasn't there a thing a while back, something about menopausal women needing to eat grass or something?

Cleo: Grass? Seaweed, Dawn.

Dawn: Oh yeah, fucking seaweed. For fuck's sake or, as my granddaughter and her friends would say, 'jog on'.

This conversation highlights the way the women differentiate themselves from those who are 'all over the place' (Dawn): union, management or HR (whether men or women). It also shows how they side-step marketisation; they noted (happily) that because they were 'normal women' on 'the change' (Cleo) they were not targeted by the menopausal business and its 'magic bullets' because of a lack of disposable income (Estes, 1993:292). Alongside, Dawn highlighted that besides the cost, 'normal women [...] haven't got time to lay about thinking about breathing' (mindfulness/yoga). However, class and/or disposable income were not the only ways in which menopausal women were othered from those on 'the change'; stupidity was called on in the second focus group:

Gail: I don't know who the women are who are taken in by the eat this, do that, don't do that.

Kate: we know our own bodies, we're not stupid. I mean, I do what's right for me. We all do, don't we? 
Iris: I read up on HRT, but more than that I talked to my friends, other women, real women, you know. [Gail and Kate both agree here]. You see what they're doing, their experiences of getting older. I wouldn't have taken it or done anything based on some sort of detached menopausal handbook.

The discourse of the menopausal woman who can lead a full life with the help of certain technologies is, arguably, one of biopower (Foucault, 2004), which seeks to control of the lives of a population: women. Clearly, women (including menopausal women) are not a homogenous group; if menopausal discourse is contained within a 'detached' handbook and considered to be directed towards middle-class or 'stupid' women it has little or no effect on 'normal women', savvy or 'real women' who are on 'the change' or simply 'getting older'. The women spoke of being 'aware of the rubbish that's spouted at women about what they should do' (Kate) and they refused to be taken in. This failure to 'correctly' target knowledge, for this targeting to be seen as a managerial lever or something of a condescending enterprise (Estes, 1993), offers opportunities for, or empowers, resistance (Foucault, 2004).

The women resist by subjugating the knowledge and what is known of the menopause (Butler, 1990; Foucault, 2004) and, seemingly, the menopause's governing and experiential effects, by downplaying its relevance. They did not see their menopause as a manageable or marketable medical condition; as such, they side-stepped absurd advice (grass or seaweed), rules of how to think (mindfulness) and/or when to breathe (yoga). Instead, they foregrounded the value of 'common sense' and of sociality (Skeggs, 2011); highlighting that being part of a community of 'real women' (Iris) made them hardier, physically, and more able to cope mentally with 'whatever ageing throws at us' (Kate).

\section{Abjection work}

When asked of 'any issues with your menopause at work?', the women often spoke in terms of the five senses, but in response to the follow-up question 'anything good?', different issues 
emerged. Specifically, the women described the sometime usefulness of their menopause. When Mary spoke of meeting with her manager following time off for 'feeling rough' she noted that 'flushing then was useful because, thing is, he can't disbelieve you when you're sitting there sweating like a pig'. Likewise, Lisa spoke of her male colleagues 'being more sympathetic if they can see you're under the weather; so being flushed or whatever can help get them off your back'. In opposition to the apparent need to take steps to make the menopausal body less visible (Kristeva, 1982; Wilson, 1966); here, it had its uses and it was sometimes used. When Nina was called in by HR to see how she 'was getting on' she said 'it was helpful when I had a flush in there - although, I did put it on a bit, you know [exaggerated fanning face].'

Nina's talk of putting it 'on a bit' was not an isolated story: far from it. In Anna's interview when asked 'if you could change anything about your job, your team, your organisation, anything, what would it be?', her response was 'the change, that's what I'd change. Seriously, that's what I'd change. Hot flushes. Never know where I am [irregular periods]. Frankly, it's quite shitty.' During the subsequent focus group, Anna was relaying this part of the interview and it was then that Beth said: 'yes, but it's fun sometimes, have you told Clare [the researcher] about that?'. The following conversation ensued:

Anna: Fun. No, I hadn't mentioned that. [All suggested she should]. Well, I'd been having hot flushes and it was really getting me down, not sleeping, like I was saying. One day I was in the boss's office, he's a right bastard, ridicules people, micro-manages, just awful. I used to hate going into see him. Anyway, one day when I was in there, I had a flush, a big one, sweat literally running from here to here [points chin to cleavage]. Oh, Christ. I got my tissue out and was flapping my top trying to, you know, but then I looked at him. He was dying. Didn't know where to look. Honestly, he looked horrified, couldn't wait to get me out of there. I don't know if he even finished the sentence. Just got me out by saying he had another meeting or something. 
Beth and Cleo: When she told us about it we were all like 'Ooh how awful for you', you know. And then we started laughing about his reaction.

Anna: He really didn't have a clue what to do. He was so embarrassed and he looked, I don't know what the word is ...

All: Pathetic? Inadequate? Useless? Weak? Small? Yes, small.

Cleo: It was after that that we decided to have fun with him.

When asked what this 'fun' involved, they explained:

Beth: It probably doesn't need saying, but I've got big boobs. When I was young they got me all sorts of things and now in my 50s they're useful again, oddly. Anytime he [boss] irritates me I just point my boobs at him and puff, you know, suggesting like I might be about to get a flush. He backs off, looks away, moves on, anything. It's fucking brilliant.

Cleo: So, we all do it now. In different ways.

Anna: I used to feel so shit about the change and, to be honest, it is still shit, but I don't know this gives you a bit of a boost.

Dawn: Christ, we sound awful, a right bunch of bitches, don't we?

That women have bodies at work is sometimes something of an inconvenience (Adamson and Johansson, 2016; Levay, 2014; Wolkowitz, 2006), but that women work their bodies at work is often regarded as something else (Wolkowitz et al., 2013). It might be considered dirty work (Hughes, 1958); physically, socially or morally questionable. However, here the working of the women's bodies is not their job; it is not part of the role, but they work their bodies at work and it 'works': colleagues are 'more sympathetic' (Lisa) or the boss 'backs off' (Beth). This raises the question of how this working of the body works.

It is useful to consider Douglas' (1966) conception of dirt as matter out of place. That a woman's breasts are discoloured and suddenly polluted with copious menopausal perspiration 
is abjecting (Kristeva, 1982): the disgusting (sweat) overlaying what might be attractive (boobs). During the process of abjection, the abject is not separated from the subject (Kristeva, 1982). Instead, an 'alien is effectively established through this expulsion'; an abject subject (Butler, 1990:169). The notable power of abjection is that which is abjected is considered distasteful, but also simultaneously compelling: a source of fascination (Kristeva, 1982). The article concludes by putting a spotlight on the working of this fascination.

\section{Concluding discussion}

This article adds to the work and employment literature by furthering our understanding of how power and menopause relate at work; and, by introducing the concept of 'abjection work'. It therefore addresses Jack et al., (2019:125) who rightly state that 'agentic appreciations of how women navigate the challenges or resist the dominant discourse on menopause is not common'.

From the women's accounts, it is clear that the menopause presented challenges; not just the symptoms, but the pressure of gendered norms and being an older woman at work (Butler, 1990, 1993, 2004; Calasanti, 2005; Duncan and Loretto, 2004; Huppatz and Goodwin, 2013; Twigg, 2004). The women were concerned about asking for support, thinking it would be interpreted as 'complaining' (Fern) (Irni, 2009). They spent their own money to make the workplace suitable and thought themselves 'a state' (Dawn) for dressing in a manner that was comfortable. When taking direct action, they considered their behaviour as 'naughty' (Beth), 'crafty' (Rosa) or underhand (and not enterprising or resourceful).

Yet, these gendered norms were open to variation (Butler, 1990). The women viewed the menopause through a feminist-sociocultural lens, a transition best managed through sociality (Skeggs, 2011): by being part of a community of women who 'got each other' (Cleo). Part of getting each other involved differentiating themselves from other women (including HR and managers); specifically, from 'menopausal' women, whether through class and/or savviness. 
In so doing, they subjugated 'detached' knowledge (Foucault, 2004) and, instead, looked to their 'common sense' knowing of their bodies and 'the change' (Nosek et al., 2012; Perz and Ussher, 2008). Through which, the women refused to be made disembodied subjects; victims of ridiculous workplace policies (Duncan and Loretto, 2004) or the menopause business (Estes, 1993).

The women's refusal of disembodiment was fashioned into body activism. This activism emerged and, often, from a rupture point (Foucault, 1978) - a bodily surprise (Jack et al., 2019). Strikingly, this power surge typically occurred within and through the process of abjection (Kristeva, 1982). For example, when Anna experienced her 'big' flush she was unable to maintain any semblance of a bodily norm (Shildrick, 1997); however, she maintained social convention by trying to repair her failure (Goffman, 1956, 1959, 1963) and by not responding to her boss's embarrassment, at least initially. However, it was the women's subsequent realisation of embarrassment's reciprocity - when the gendered bodily norms were incoherent and 'run rampant' (Butler, 1990:173) - that offered conditions for agency. This materialisation of a 'body politics of surprise' (Jack et al., 2019:122) ignited discontinuity and established a new being - an 'alien' (Butler, 1990:169) - who took a sideways glance at appropriateness and the downplaying of embarrassing 'gender displays' (Goffman, 1979:1) and offered 'the possibility of a variation on repetition' (Butler, 1990:185) through the up-playing of embarrassment.

Embarrassment arises from norm-breaking (Goffman, 1956, 1959, 1963). It can be vicarious (Gross and Stone, 1964); for example, when watching someone suddenly resemble ‘Tinky Winky' (Anna). Of course, you can embarrass yourself (Goffman, 1956) or others (Swiss, 1982), but you can also 'do' embarrassment. That is, embarrassment can be a performance, which is then performative (i.e. it has an effect). Doing embarrassment is a signal 
of pro-sociality, whether feigned or otherwise, and its most powerful performative effect is the heightening of interpersonal connectivity (Feinberg et al., 2012).

Drawing on the women's stories, it is argued that it is through performing - doing embarrassment, while displaying an 'abject appearance' (Mavin and Grandy, 2016:1095), that offered the women agency. Their apparently abject bodies, when conceptualised within the social process of abjection, disturbed 'identity, system, order' (Kristeva, 1982:4); affecting subjectivities sufficiently to empower the women to bring another more agentic being into being (Butler, 1990; Dillaway, 2005; Perz and Ussher, 2008). In this complex of performance, the women drew on vicarious embarrassment, which was made more powerful by the compelling nature of abjection (Kristeva, 1982) combined with the invocation of empathetic embarrassment: as the women are observed trying to repair their apparent or imminent failure (Goffman, 1956, 1959, 1963) by 'flapping' their top (Anna), hand (Nina) or pre-emptively puffing (Beth).

Accordingly, and in stark contrast to prior work, abjection was not practised on the women (Gatrell, 2019); they did not seek to distance themselves from abjection (Rizq, 2013) or minimise their 'abject appearance' (Haynes, 2012; Mavin and Grandy, 2016:1095). Instead, the women reconceptualised abjection as a sometime compelling and workable fascination. Adding to the academic literature, the women's efforts are encapsulated by the concept of 'abjection work': a manner of body work that draws on the reciprocity of embarrassment and compelling fascination of abjection, which together act as a powerful form of management.

More is to be done to build on this article's contribution, and the work of others (Brewis et al., 2017; Gatrell, 2019; Hardy et al., 2017; Jack et al., 2019). The study reflects the experiences and actions of 23 women in their 50s who work as UK local government administrators. Therefore, context, location, role, along with sample size, need to be considered 
in assessing its themes. Yet, the research shines a spotlight on how (some) women navigate the menopause at work; a woefully under-researched topic. The study's somewhat surprising findings - the fascination of older women's employment of their bodies - emphasises just how little is known of women's body-work at work (Wolkowitz, 2002), still (Rydzik and EllisVowles, 2019). If nothing else, this research shows that bodies and the surrounding power dynamics at work are never simple. It also highlights that there is much more to learn about abjection and the role that being abject - embodying both 'fear and fascination' (Kristeva, 1982:45) - has on people's working lives and navigation of work.

\section{Acknowledgements}

I would like to thank the women who took part in this study for their wisdom, candour, generosity and 'common sense': never has research been so much fun! Thanks also to the three reviewers for their thoughtfulness and insightful suggestions. The article was much improved as a result of your efforts. Finally, I am very grateful to Sophie Jacques at the British Sociological Association and the article's Editor - Dr Alexandra Beauregard - for their expertise, care and hard work. Thank you.

\section{Funding}

The author received no financial support for the research, authorship, and/or publication of this article.

\section{References}

Adamson M and Johansson M (2016) Compositions of professionalism in counselling work: an embodied and embedded intersectionality framework. Human Relations 69(12):2201-2223.

Atkinson C, Ford J, Harding N and Jones F (2015) The expectations and aspirations of a latecareer professional woman. Work, Employment and Society 29(6):1019-1028.

Ballard KD, Kuh DJ and Wadsworth MEJ (2001) The role of the menopause in women's experiences of the 'change of life'. Sociology of Health \& Illness 23(4):397-424. 
Beck V and Williams G (2015) The (performance) management of retirement and the limits of individual choice. Work, Employment and Society 29(2):267-277.

Bell SE (1987) Changing ideas: the medicalization of menopause. Social Science \& Medicine 24(6):535-542.

Brewis J, Beck V, Davies A and Matheson J (2017) Menopause Transition: Effects on Women's Economic Participation. UK: Department for Education

Budd JW and Spencer DA (2015) Worker well-being and the importance of work: bridging the gap. European Journal of Industrial Relations 21(2):181-196.

Butler C (2015) Making interview transcripts real: the reader's response. Work, Employment and Society 29(1):166-176.

Butler J (1989) Foucault and the paradox of bodily inscriptions. The Journal of Philosophy 86(11):601-607.

Butler J (1990) Gender Trouble: Feminism and the Subversion of Identity. New York:

Routledge.

Butler J (1993) Bodies that Matter:On the Discursive Limits of "Sex". New York: Routledge.

Butler J (1997) The Psychic Life of Power: Theories in Subjection. Stanford, California:

Stanford University Press.

Butler J (2004) Undoing Gender. London: Routledge.

Calasanti T (2005) Ageism, gravity, and gender: experiences of ageing bodies. Generations 29(3):8-12.

Coupland J and Williams A (2002) Conflicting discourses, shifting ideologies:

pharmaceutical, 'alternative' and feminist emancipatory texts on the menopause.

Discourse \& Society 13(4):419-445.

Delanoë D, Hajri S, Bachelot A, Mahfoudh Draoui D, Hassoun D, Marsicano E and Ringa V (2012) Class, gender and culture in the experience of menopause: a comparative survey in Tunisia and France. Social Science \& Medicine 75(2):401-409.

Dillaway HE (2005) Menopause is the "good old": women's thoughts about reproductive aging. Gender and Society 19(3):398-417.

Douglas M (1966) Purity and Danger: An Analysis of Concepts of Pollution and Taboo. London: Routledge.

Duncan C and Loretto W (2004) Never the right age? gender and age-based discrimination in employment. Gender, Work \& Organization 11(1):95-115.

Estes CL (1993) The aging enterprise revisited. The Gerontologist 33(3):292-298. 
Farrugia D (2018) Youthfulness and immaterial labour in the new economy. The Sociological Review 66(3):511-526.

Feinberg M, Willer R and Keltner D (2012) Flustered and faithful: embarrassment as a signal of prosociality. Journal of Personality and Social Psychology 102(1):81-97.

Ferguson SJ and Parry C (1998) Rewriting menopause: challenging the medical paradigm to reflect menopausal women's experiences. Frontiers: A Journal of Women Studies 19(1):20-41.

Fishman JR, Flatt MA and Settersten RA (2015) Bioidentical hormones, menopausal women, and the lure of the "natural" in US anti-aging medicine. Social Science \& Medicine 132:79-87.

Fotaki M (2013) No woman is like a man (in academia): the masculine symbolic order and the unwanted female body. Organization Studies 34(9):1251-1275.

Foucault M (1978) The History of Sexuality, Volume I. New York: Vintage.

Foucault M (1979) Discipline and Punish: The Birth of the Prison. Harmondsworth: Penguin Books.

Foucault M (1988) Technologies of the self. In: Martin LH, Gutman H and Hutton PH (eds) Technologies of the Self: A Seminar with Michel Foucault. London: University of Massachusetts Press, 16-49

Foucault M (2004) Society Must Be Defended: Lectures at the Collège de France, 1975-76. London: Penguin.

Gannon L and Ekstrom B (1993) Attitudes toward menopause: the influence of sociocultural paradigms. Psychology of Women Quarterly 17(3):275-288.

Gardiner J, Robinson AM and Fakhfakh F (2016) Exploring the private pension gender gap and occupation in later working life. Work, Employment and Society 30(4):687-707.

Gatrell C (2019) Boundary creatures? employed, breastfeeding mothers and 'abjection as practice'. Organization Studies 40(3):421-442.

Goffman E (1956) Embarrassment and social organisation. The American Journal of Sociology 62(3):264-271.

Goffman E (1959) The Presentation of Self in Everyday Life. London: Penguin.

Goffman E (1963) Behavior in Public Places: Notes on the Social Organization of Gatherings. New York: The Free Press.

Goffman E (1977) The arrangement between the sexes. Theory and Society 4(3):301-331. Goffman E (1979) Gender Advertisements. Cambridge, MA: Harvard University Press. 
Goffman E (1983) The interaction order: American Sociological Association, 1982 presidential address. American Sociological Review 48(1):1-17.

Green EE, Thompson D and Griffiths F (2002) Narratives of risk: women at midlife, medical 'experts' and health technologies. Health, Risk \& Society 4(3):273-286.

Green J and Thorogood N (2014) Qualitative Methods for Health Research. London: SAGE.

Gross E and Stone GP (1964) Embarrassment and the analysis of role requirements. American Journal of Sociology 70(1):1-15.

Guillemin M (2000) Working practices of the menopause clinic. Science, Technology, \& Human Values 25(4):449-471.

Hardy C, Griffiths A and Hunter MS (2017) What do working menopausal women want? a qualitative investigation into women's perspectives on employer and line manager support. Maturitas 101:37-41.

Haynes K (2008) (Re)figuring accounting and maternal bodies: the gendered embodiment of accounting professionals. Accounting, Organizations and Society 33(4-5):328-348.

Haynes K (2012) Body beautiful? gender, identity and the body in professional services firms. Gender, Work \& Organization 19(5):489-507.

Hughes EC (1958) Men and their Work. Glencoe, IL: The Free Press.

Huppatz K and Goodwin S (2013) Masculinised jobs, feminised jobs and men's 'gender capital' experiences: understanding occupational segregation in Australia. Journal of Sociology 49(2-3):291-308.

Ingold J and Etherington D (2013) Work, welfare and gender inequalities: an analysis of activation strategies for partnered women in the UK, Australia and Denmark. Work, Employment and Society 27(4):621-638.

Irni S (2009) Cranky old women? irritation, resistance and gendering practices in work organizations. Gender, Work \& Organization 16(6):667-683.

Itzin C and Phillipson C (1995) The double jeopardy of age and gender. In Itzin C and Newman J (eds) Gender, Culture and Organisation Change. London: Routledge, 8190.

Jack G, Riach K and Bariola E (2019) Temporality and gendered agency: menopausal subjectivities in women's work. Human Relations 72(1):122-143.

Jack G, Riach K, Bariola E, Pitts M, Schapper J and Sarrel P (2016) Menopause in the workplace: what employers should be doing. Maturitas 85:88-95.

Johansson J, Tienari J and Valtonen A (2017) The body, identity and gender in managerial athleticism. Human Relations 70(9):1141-1167. 
Jyrkinen M and McKie L (2012) Gender, age and ageism: experiences of women managers in Finland and Scotland. Work, Employment and Society 26(1):61-77.

Kafanelis BV, Kostanski M, Komesaroff PA and Stojanovska L (2009) Being in the script of menopause: mapping the complexities of coping strategies. Qualitative Health Research 19(1):30-41.

Kaufert PA (1982) Myth and the menopause. Sociology of Health \& Illness 4(2):141-166.

Klein R and Dumble LJ (1994) Disempowering midlife women: the science and politics of hormone replacement therapy (HRT). Women's Studies International Forum 17(4):327343.

Komesaroff PA, Rothfield P and Daly J (1997) Reinterpreting Menopause: Cultural and Philosophical Issues. New York: Routledge.

Kristeva J (1982) Powers of Horror: An Essay on Abjection. New York: Columbia University.

Levay C (2014) Obesity in organizational context. Human Relations 67(5):565-585.

Loretto W and Vickerstaff S (2015) Gender, age and flexible working in later life. Work, Employment and Society 29(2):233-249.

Loretto W, Vickerstaff S and White P (2009) The Future for Older Workers: New Perspectives. The Policy Press: Bristol, UK.

Lyons AC and Griffin C (2003) Managing menopause: a qualitative analysis of self-help literature for women at midlife. Social Science \& Medicine 56(8):1629-1642.

Martin E (1988) Medical metaphors of women's bodies: menstruation and menopause. International Journal of Health Services 18(2):237-254.

Mavin S and Grandy G (2016) A theory of abject appearance: women elite leaders' intragender 'management' of bodies and appearance. Human Relations 69(5):1095-1120.

Miles MB and Huberman AM (1994) Qualitative Data Analysis. Thousand Oaks, CA: Sage Publications.

Mishra G and Kuh D (2006) Perceived change in quality of life during the menopause. Social Science \& Medicine 62(1):93-102.

Mishra GD and Kuh D (2012) Health symptoms during midlife in relation to menopausal transition: British prospective cohort study. BMJ 344(e402).

Murtagh MJ and Hepworth J (2003) Menopause as a long-term risk to health: implications of general practitioner accounts of prevention for women's choice and decision-making. Sociology of Health \& Illness 25(2):185-207. 
Niland P and Lyons AC (2011) Uncertainty in medicine: meanings of menopause and hormone replacement therapy in medical textbooks. Social Science \& Medicine 73(8):1238-1245.

Nosek M, Kennedy HP and Gudmundsdottir M (2012) 'Chaos, restitution and quest': one woman's journey through menopause. Sociology of Health \& Illness 34(7):994-1009.

Padamsee TJ (2011) The pharmaceutical corporation and the 'good work' of managing women's bodies. Social Science \& Medicine 72(8):1342-1350.

Perz J and Ussher JM (2008) "The horror of this living decay": women's negotiation and resistance of medical discourses around menopause and midlife. Women's Studies International Forum 31(4):293-299.

Phillipson C, Vickerstaff S and Lain D (2016) Achieving fuller working lives: labour market and policy issues in the United Kingdom. Australian Journal of Social Issues 51(2):187-203.

Rizq R (2013) States of abjection. Organization Studies 34(9):1277-1297.

Rydzik A and Ellis-Vowles V (2019) 'Don't use "the weak word"”: women brewers, identities and gendered territories of embodied work. Work, Employment and Society 33(3):483-499.

Shildrick M (1997) Leaky Bodies and Boundaries: Feminism, Postmodernism and (Bio)ethics. London: Routledge.

Skeggs B (2011) Imagining personhood differently: person value and autonomist workingclass value practices. The Sociological Review 59(3):496-513.

Smeaton D and White M (2018) Britain's older employees in decline, 1990-2006: a panel analysis of pay. Work, Employment and Society 32(1):93-113.

Smirnova M and Owens JG (2017) Medicalized addiction, self-medication, or nonmedical prescription drug use? how trust figures into incarcerated women's conceptualization of illicit prescription drug use. Social Science \& Medicine 183:106-115.

Swiss JE (1982) Publicizing organizational performance goals: self-embarrassment as a management strategy. The American Review of Public Administration 16(2-3):209-215.

Taylor P, Warhurst C, Thompson P and Scholarios D (2009) 'On the Front Line', Work, Employment and Society 23(7): 7-11.

Twigg J (2004) The body, gender, and age: feminist insights in social gerontology. Journal of Aging Studies 18(1):59-73. 
van den Berg M and Arts J (2019) The aesthetics of work-readiness: aesthetic judgements and pedagogies for conditional welfare and post-Fordist labour markets. Work, Employment and Society 33(2):298-313.

van der Horst M, Lain D, Vickerstaff S, Clark C and Baumberg Geiger B (2017) Gender roles and employment pathways of older women and men in England. SAGE Open 7(4):1-17.

Wilson RA (1966) Feminine Forever. New York: Evans.

Wolkowitz C (2002) The social relations of body work. Work, Employment and Society $16(3): 497-510$.

Wolkowitz C (2006) Bodies at Work. London: Sage.

Wolkowitz C, Cohen RL, Sanders T and Hardy K (eds) (2013) Body/Sex/Work: Intimate, Embodied and Sexualised Labour, Basingstoke: Palgrave.

Woyka J (2017) Consensus statement for non-hormonal-based treatments for menopausal symptoms. Post Reproductive Health 23(2):71-75.

Zou M (2015) Gender, work orientations and job satisfaction. Work, Employment and Society 29(1):3-22. 